\title{
Identification of Molecular Markers for Selected Wood Properties of Norway Spruce Picea abies L. (Karst.) I. Wood Density
}

\author{
By T. Markussen(忷), A. Tusch, B. R. Stephan and M. Fladung
}

\begin{abstract}
Federal Research Centre for Forestry and Forest Products (BFH), Institute for Forest Genetics and Forest Tree Breeding,
\end{abstract} Sieker Landstrasse 2, D-22927 Großhansdorf, Germany

(Received 19 $9^{\text {th }}$ April 2002)

\begin{abstract}
The identification of AFLP markers and their subsequent conversion to SCAR-markers linked to wood density of Norway Spruce (Picea abies L [Karst.]) is described for the first time. In AFLP-analyses, 102 different primer enzyme combinations were screened in a bulked segregant approach comparing individuals with high and low wood density. A total of 107 polymorphic AFLP fragments were obtained between the DNA-pools. Twenty-three markers were selected for further analyses to verify their linkage to wood density based on individuals used for pool constitution and additional unrelated clonal material. For 15 markers, a significant linkage to wood density was confirmed by a two-sided Fisher's-exact test. Four markers were converted into SCAR markers and validated for plant material assayed for wood density by X-ray microdensitometry. For each marker a monomorphic band was obtained using sets of nested primers or restriction site-specific primers (RSS), which include the AFLP-restriction recognition sites. For two markers that are linked to high wood density, a separation from unlinked size homologous marker-alleles was realized by a PCR-restriction approach. Validation of these markers in different full-sib families confirmed their usability to separate the classes for low and high wood density of Picea abies.
\end{abstract}

Key words: AFLP, Bulked segregant analysis, Marker assisted selection (MAS), Molecular markers, Wood properties.

\section{Introduction}

Norway spruce (Picea abies (L.) Karst) is one of the most important forest tree species in the northern hemisphere and of tremendous ecological and economical importance for forestry and wood production. Several industrial branches are concerned with production of solid wood, panels, veneer, fibres, boards or pulps. The economical value of these products, however, is affected by the quality of technological and anatomical properties of the raw wood material.

Among the different wood properties such as chemical characteristics (lignin and extractives content), module of elasticity, spiral grain and fibre characteristics, wood density is the key property in forest products. It has a major effect on both yield and quality of fibrous and solid wood products (ZOBEL and VAN Buituenen, 1989) and considerable influence on strength, machinability, conversion, wearability, paper yield and properties (BAMBER and BURLEY, 1983).

The quality of wood density is a result of long term processes based on genetic propositions and interaction with environmental factors. Due to shorter rotations, the proportion of juvenile wood of harvested trees is increasing, but the quality of softwood, concerning wood density is decreasing (KenNEDY, 1995). One way to reduce this loss of quality is to genetically improve wood properties (ROZENBERG and CAHALAN, 1997).

*Author for further correspondence: t.markussen@holz.uni-hamburg.de,
Phone: +49 (0)4102696157, Fax: +49 (0)4102696200
For an improvement, many endeavours have been undertaken to increase the knowledge about molecular basis of wood properties (McKAY et al., 1995; ZHANG et al., 1997; Wu et al., 1999). Genetic maps have been established for different forest tree species (Plomion et al., 1995; REMington et al., 1999; ARCADE et al., 2000; RITTER et al., 2002) and many more quantitative trait loci (QTLs) influencing traits like growth, form and phenology in Populus trichocarpa $\mathrm{x}$ deltoides (BRADSHAW and SteTtler, 1995), growth height in Pinus pinaster (Plomion et al., 1996), frost tolerance in Eucalyptus nitens (BYRNE et al., 1997), height and diameter in Pinus sylvestris (LERCETEAU et al., 2000) or monoterpene composition in Eucalyptus grandis (SHEPARD et al., 1999) have been reported.

Due to the economical importance of wood density, the requirement is justified to obtain a more detailed knowledge about genes which are responsible for wood density expression and to examine their complexity in relation to other traits. Several reports on the genetic architecture of wood density in forest trees have been published, i.e. the number of genes, location on chromosomes, mode of action and magnitude of effects, indicate the existence of major genes influencing wood density in trees such as Pinus taeda (GROOver et al., 1994; SEWELL et al., 2000), Eucalyptus grandis (GratTAPAGLIA et al., 1996), Eucalyptus globulus (THAMARus et al., 2000) and Pinus radiata (Kumar et al., 2000).

These studies will be useful in understanding about the complexity of wood properties, and may also affect forest tree breeding in the future. For example, they may offer the opportunity to improve wood properties by gene combination via marker-assisted selection (pyramiding), by genetic engineering (LóPEZ et al., 2000; ClAPHAM et al., 2000) or by silencing of genes coding for undesired traits (SEDEROFF, 1999).

The major obstacle for improving wood properties, is the time necessary to complete a breeding generation. Current practice has relied almost exclusively on the analysis of traits at rotation age. For traits of economical value, early selection of individual trees is efficient half-way through rotation. Tree breeding is even more difficult by the changes occur during the transition from juvenile to mature wood. Wood density is only adequately expressed at the phenotypic level after the tree has produced several growth rings, and early growth heights are often a poor predictor for wood density at rotation age.

Methods to improve the accuracy of early selection at the individual level would be of considerable value to increase the genetic gain per unit time. In that respect, a promising method is the identification of genotypes using a diagnostic system based on molecular markers. Selection for wood density by usage of molecular markers will have an enormous impact on cost reduction for breeding programmes, and it will be of importance for the forest manufacturing industry, by guaranteeing the highest and equal wood quality products.

Despite the identification of QTLs for wood density, the conversion of QTL-markers into PCR-based markers and their 
usefulness for marker assisted selection approaches are mostly published for crop species (OBERHAGEMANN et al., 1999; SHAN et al., 1999; MeKsem et al., 2001) but to our knowledge no report is conversant for coniferous species concerning this topic.

In this paper, we report the use of bulked segregant analysis (MichELMORE et al., 1991) in combination with AFLP - marker technology (Vos et al., 1995) to identify molecular markers for wood density. Individuals of different unrelated families were used for bulking to support the confidence of the selected markers. Three putative molecular markers for high wood density and one for low wood density were selected and converted into SCAR markers. The markers were validated in unrelated Norway spruce families.

\section{Materials and Methods}

\section{Plant Materials}

The plant material was provided by SkogForsk, Uppsala, Sweden within the EU funded project GENIALITY (http:// www. skogforsk.se/geniality). A total of 222 individuals was tested, representing 29 different Norway spruce full sib families from the Swedish stand Karlsbol (S22F58241A; lat. 59 $6^{\circ}$, long. $13^{\circ} 6$, alt. $80 \mathrm{~m}$ ) established in 1958. Furthermore, 42 clones from the Swedish stand Hermanstorp (S31S7820002; lat. $56^{\circ} 45^{\prime}$, long. $15^{\circ} 02^{\prime}$, alt. $180 \mathrm{~m}$ ) and 30 clones from Knutstorp (S31S7820003; lat. $55^{\circ} 58^{\prime}$, long. $13^{\circ} 18^{\prime}$, alt. $75 \mathrm{~m}$ ) established in 1978 were supplied for the analyses. 20 clones were common to both tests. Additional, a total of 20 ramets from the Swedish stand Maglehem ( lat. 55 ${ }^{\circ} 46^{\prime}, 14^{\circ} 10^{\prime}$, planted in 1956 onwards) supplied by SkogForsk and 40 unrelated clones from IUFRO-trial 1-360 (Amance domanial forest; Meurthe et Moeselle, France) supplied by INRA were involved in the analyses.

\section{Estimation of wood density}

Wood density was estimated by INRA-Orléans (ROzENBERG et al., 2001) using the radiation method of indirect X-ray microdensity (PoLGE, 1966) and modern computation techniques (ROZENBERG and Franc, 1996). One radial X-ray density profile was obtained from each sample (disks) and each disk was sawn to a $2.00 \mathrm{~mm}( \pm 0.02 \mathrm{~mm})$ thick wood strip. The indirect method measures the attenuation of a very thin $(250 \times 24$ microns in this case) light ray crossing the X-ray picture of a wood sample. Density profiles were separated into rings, using functions developed under Splus statistical software (www.insightful.com). For estimation of within ring variables, each ring was identified chronologically by two parameters: the ring number from pith to bark (cambial age at time of ring formation); and the calendar year in which the ring was formed (determined by counting from bark to pith). The average wood density for each individual was calculated based on results of the entire sample. Wood density for the 20 ramets (Sweden) and 40 clones (France), was estimated indirectly by the method of Pilodyn measurement (pin depth penetration).

\section{AFLP analyses}

DNA was extracted from spruce needles according to a protocol of DumoLin et al. (1995). AFLP fingerprints were generated based on the modified protocol described by Vos et al. (1995). A total of $250 \mathrm{ng}$ genomic DNA was restricted with either EcoRI and MseI, PstI and MseI or HindIII and MseI (4-5U of each) for $2-2.5 \mathrm{~h}$ at $37^{\circ} \mathrm{C}$ in $1 \times$ restriction buffer OPA (One-Phor-all; Amersham-Pharmacia, Freiburg, Germany) in a final volume of $50 \mu \mathrm{l}$. After controlling for complete digestion, $10 \mu \mathrm{l}$ of a ligation mix [50 pmol MseI adapter, 5 pmol EcoRI, PstI or HindIII adapter, $10 \mathrm{mM}$ ATP, $1 \times$ OPA buffer and $2.5 \mathrm{U}$ T4 DNA ligase] was added and the samples incubated for $3 \mathrm{~h}$ at $37^{\circ} \mathrm{C}$.
A pre-amplification reaction was performed in a $50 \mu \mathrm{l}$ reaction containing: $5 \mu \mathrm{l}$ of template DNA, $150 \mathrm{ng}$ of $M s e \mathrm{I}, E c o R I$, $P s t \mathrm{I}$ and HindIII primer with one nucleotide extension, 0.25 $\mathrm{mM}$ dNTPs, 1 x PCR buffer, $1.2 \mathrm{mM} \mathrm{MgCl}_{2}$ and $1 \mathrm{U}$ Taq Polymerase (Eurogentec, Seraing, Belgium; Silverstar Taq and buffer). Samples were run on a TGradient cycler (Biometra, Göttingen, Germany) using the following cycling parameter: initial denaturation step $94^{\circ} \mathrm{C}(1 \mathrm{~min}), 19$ cycles of $94^{\circ} \mathrm{C}(30 \mathrm{~s})$, $60^{\circ} \mathrm{C}(30 \mathrm{~s}), 72^{\circ} \mathrm{C}(1 \mathrm{~min})$ and a final extension $72^{\circ} \mathrm{C}(5 \mathrm{~min})$. The pre-amplified DNA was diluted (1:5) and equal aliquots of DNA from each individual selected for the different bulks was mixed and used for selective amplification. Selective amplifications were performed in a $20 \mu \mathrm{l}$ reaction containing: $5 \mu \mathrm{l}$ of the diluted template DNA, 10 ng EcoRI, PstI, HindIII primer (Cy5 labelled, MWG-Biotech, Ebersberg, Germany) and $50 \mathrm{ng}$ MseI primer each having three selective nucleotides, 1 x PCR buffer. $1.2 \mathrm{mM} \mathrm{MgCl}$, and $1 \mathrm{U}$ Taq Polymerase and buffer (Eurogentec, Seraing, Belgium). Samples were run on a TGradient cycler (Biometra, Göttingen, Germany) using the following cycling parameter: initial denaturation step $94^{\circ} \mathrm{C}$ (5 min); $1 \mathrm{x}$ $94^{\circ} \mathrm{C}(30 \mathrm{~s}), 65^{\circ} \mathrm{C}(30 \mathrm{~s}), 72^{\circ} \mathrm{C}(1 \mathrm{~min}) ; 2 \times 94^{\circ} \mathrm{C}(30 \mathrm{~s}), 64^{\circ} \mathrm{C}(30$ $\mathrm{s}), 72^{\circ} \mathrm{C}(1 \mathrm{~min}) ; 2 \times 94^{\circ} \mathrm{C}(30 \mathrm{~s}), 62^{\circ} \mathrm{C}(30 \mathrm{~s}), 72^{\circ} \mathrm{C}(1 \mathrm{~min}) ; 2 \mathrm{x}$ $94^{\circ} \mathrm{C}(30 \mathrm{~s}), 58^{\circ} \mathrm{C}(30 \mathrm{~s}), 72^{\circ} \mathrm{C}(1 \mathrm{~min}) ; 23 \times 94^{\circ} \mathrm{C}(30 \mathrm{~s}), 56^{\circ} \mathrm{C}$ $(30 \mathrm{~s}), 72^{\circ} \mathrm{C}(1 \mathrm{~min})$ and a final extension $72^{\circ} \mathrm{C}(5 \mathrm{~min}) .8 .5 \mathrm{\mu l}$ reaction products were resolved on high-resolution polyacrylamide gels on the automatic sequencer ALFexpress II (Amersham-Pharmacia, Freiburg, Germany) and fragments were detected and analysed by using the Fragment Analyser software (Vers. 1.03; Amersham-Pharmacia, Freiburg, Germany). The bulks were compared for each primer enzyme combination (PEC) at polymorphic fragments which reflect putative markers linked with low or high wood density. For each primer enzyme combination (PEC), the bulks were compared on polymorphic fragments, reflecting putative markers linked with high or low extractives content. In the following, each individual used for bulk constitution (high and low extractives content), was analysed separately on presence or absence of putative markers. The significance level for correlation of these markers to high or low extractives content was estimated by a two-sided Fisher exact test.

\section{Conversion of AFLP into SCAR marker}

The fragments (see below) were isolated from a high resolution polyacrylamide gel (Amersham-Pharmacia, Freiburg, Germany) and purified by using the QIAEX II-Kit (QIAGEN, Hilden, Germany) according to manufacturer instructions. The fragments were reamplified by using the unlabeled set of specific AFLP primer pair of the corresponding selective amplification in an final volume of $50 \mu \mathrm{l}$. A $10 \mu \mathrm{l}$ sample of each PCR product was electrophoresed on a $2 \%$ agarose gel for size comparison. Concentration of the PCR products was determined and an aliquot was cloned using the TOPO TA Cloning Kit for Sequencing (Invitrogen, Carlsbad, Calif. USA) according to the protocol of the manufacturer. Ninty six colonies were chosen from each transformation event, and transferred to a microtiter plate containing $100 \mu \mathrm{l} \mathrm{LB}$-media with $50 \mu \mathrm{g} / \mathrm{ml}$ of ampicillin and cultured overnight. A one $\mu \mathrm{l}$ aliquot of each culture was amplified by PCR using the M13 forward- and reverse-primer and the product screened on $1.4 \%$ agarose gels for size homology to the corresponding AFLP fragment. Ten clones were selected and sequenced using the BIG-Dye Terminator Sequencing-Kit (PE Applied Biosystems, Foster City, USA) according to the instructions of the manufacturer. Primers were designed using the Primer 3 program (www.genome.wi.mit.edu/cgi/cgi-bin/primer/primer3_www.cgi). PCR reactions were performed in a $25 \mu \mathrm{l}$ reaction containing: 
$25 \mathrm{ng}$ template DNA, $25 \mathrm{pg}$ of each primer, $1 \mathrm{x}$ Williams-buffer modified (WiLliams et al., 1991) (10 mM Tris-HCl pH 8.3, $50 \mathrm{mM} \mathrm{KCl}, 2.0 \mathrm{mM} \mathrm{MgCl} 2,0.001 \%$ gelatine) and $1 \mathrm{U}$ Taq Polymerase (Eurogentec, Seraing, Belgium). Samples were run on a Tgradient cycler (Biometra, Göttingen, Germany) using the following cycling parameters: initial denaturation step $94^{\circ} \mathrm{C}$ (3 min); $4 \mathrm{x} 94^{\circ} \mathrm{C}(1 \mathrm{~min}), \mathrm{Tm}(1 \mathrm{~min}), 72^{\circ} \mathrm{C}(1 \mathrm{~min}) ; 36 \mathrm{x} 94^{\circ} \mathrm{C}$ $(30 \mathrm{~s}), \operatorname{Tm}(30 \mathrm{~s}) ; 72^{\circ} \mathrm{C}(30 \mathrm{~s}) ; 1 \times 94^{\circ} \mathrm{C}(30 \mathrm{~s}), \operatorname{Tm}(30 \mathrm{~s})$ and $72^{\circ} \mathrm{C}(5 \mathrm{~min})(\mathrm{Tm}$ see Table 3). PCR-products were electrophoresed on a $2 \%$ ethidium-bromide stained agarose-gel. For the restriction of PCR-products, $1 \mathrm{U}$ restriction enzyme per $25 \mu \mathrm{l}$ PCR-reaction was used.

\section{Database comparison and statistics}

Sequence of the fragment was compared to the MAFF DNA Bank (http://www.dna.affrc.go.jp/) by BLAST N- and BLAST Xsearch. Analysis of Variance of wood density in relation to marker classes was carried out by SAS software Vers. 6.1 particularly using Proc ANOVA and the LSD test for the comparison of means.

\section{Results}

\section{AFLP analyses}

Four DNA-pools were applied to carry out genotyping of individuals with most extreme wood densities of Norway spruce which represent different full-sib families. Two different pairs of pools with 15 and 10 individuals, respectively were tested for both for high and low wood density, respectively. In total, 34 primer enzyme combinations (PECs) each for EcoRI/MseI, PstI/MseI and HindIII/MseI (all 3bp extension) were analysed for identifying polymorphisms between the pools. Polymorphisms were selected, being present in each pair of samples and absent in the other.
A total of 107 polymorphic bands were identified as putatively correlated to high or low wood density, respectively. Twentythree polymorphic bands, showing strongest band intensities and distant position to neighbouring bands, were selected for further analysis. To confirm the polymorphisms observed in the DNA pools, each individual, used for pool construction, and additionally unrelated clonal material was analysed separately for on presence or absence of the polymorphic AFLP-fragments. (Table 1). Fifteen fragments were significantly correlated to low or high wood density according to a two side Fisher's exact test (Table 1). Four polymorphic fragments, showing the lowest deviation from the expected pattern of presence/absence of the markers in corresponding individuals, were selected for conversion into SCAR markers (Table 1, bold italics).

\section{Characterization and validation of SCAR marker}

Conversion of the four selected polymorphic AFLP fragments (K9-171, K37-263, K67-166 and K68-325, Table 1, bold) into SCAR marker was started from the bulked DNA. Following reamplification and sequencing of the bands, significant sequence differences were observed for the different clones, suggesting sequence similarities between the different clones.

For fragment K9-171 and K37-263, both, the PstI- and MseI adaptor sequence was identified as expected, whereas for fragment K67-166 and K68-325, only the PstI adaptor sequence was identified on both ends of the fragments. Additionally, a sequence deviation for the overhang from CCA to CTG was detected for fragment K68-325 (Table 2B, italics).

By BLAST N sequence comparisons, homologies to cDNA of P. taeda were found for marker K37-263 and K68-325, while by BLAST X search, high homologies to Arabidopsis ESTs were found for markers K9-171 (60\%) and K68-325 (75\%). Additionally, homology of $82 \%$ to protein phosphatase from Arabidopsis was identified for K37-263.

Table 1. - Results of the two-sided fisher-exact-test performed for the estimation of marker linkage to wood density. 15 marker were selected as significantly correlated to wood density in total. a: primersequences specific for adaptor: $\mathrm{P}=P s t \mathrm{I} ; \mathrm{E}=E \operatorname{EcoRI} ; \mathrm{H}=$ Hind III; $\mathrm{M}=M s e \mathrm{I}+3 \mathrm{bp}$ extension. b: number of individuals having high wood density as determined by X-ray microdensity and pilodyn measurement out of 58 individuals ( 25 individuals from the full sib families used for bulk construction and 33 additional unrelated clones from Sweden and France). c: number of individuals having low wood density as determined by X-ray microdensity and pilodyn measurement out of 60 individuals ( 25 individuals from the full sib families used for bulk construction and 35 additional unrelated clones from Sweden and France). $\mathrm{d}$ : number of deviations from the expectation on presence or absence of fragments out of 118 individuals.

\begin{tabular}{|ll|l|l|c|c|c|c|}
\hline PEC $^{\mathrm{a}}$ & bp & character & High density $^{b}$ & Low density $^{c}$ & ${\text { Deviation events } \%^{\text {d }}}^{\text {p-value }}$ \\
\hline K5 & PCCA/MATG & 258 & high density & $29(58)$ & $19(60)$ & $48(118) / 40.1$ & 0.0605 \\
\hline K9 & PCCA/MCAG & 171 & high density & $38(58)$ & $7(60)$ & $27(118) / 22.8$ & $<0.05$ \\
\hline K30 & PCCA/MACG & 386 & high density & $15(58)$ & $14(60)$ & $57(118) / 48.3$ & 0.8319 \\
\hline K34 & PCCA/MCCG & 166 & high density & $43(58)$ & $23(60)$ & $38(118) / 32.2$ & $<0.05$ \\
\hline K37 & PCCA/MCGC & 263 & high density & $41(58)$ & $6(60)$ & $23(118) / 19.5$ & $<0.05$ \\
\hline K63 & PCCA/MGGC & 163 & high density & $25(58)$ & $18(60)$ & $51(118) / 43.2$ & 0.1808 \\
\hline K67 & PCCA/MTCG & 166 & high density & $37(58)$ & $8(60)$ & $29(118) / 23.7$ & $<0.05$ \\
\hline K97 & EAAC/MTCG & 427 & high density & $36(58)$ & $17(60)$ & $39(118) / 32.9$ & $<0.05$ \\
\hline K99 & EAAC/MTTC & 357 & high density & $32(58)$ & $14(60)$ & $40(118) / 33.9$ & $<0.05$ \\
\hline K14 & HACC/MATG & 94 & high density & $37(58)$ & $39(60)$ & $60(118) / 50.8$ & 1.00 \\
\hline K30 & PCCA/MACG & 552 & low density & $29(58)$ & $38(60)$ & $51(118) / 43.2$ & 0.1932 \\
\hline K32 & PCCA/MAGC & 500 & low density & $9(58)$ & $24(60)$ & $45(118) / 38.1$ & $<0.05$ \\
\hline K37 & PCCA/MCGC & 312 & low density & $24(58)$ & $32(60)$ & $52(118) / 44.0$ & 0.2035 \\
\hline K63 & PCCA/MGGC & 180 & low density & $15(58)$ & $28(60)$ & $47(118) / 36.4$ & $<0.05$ \\
\hline K64 & PCCA/MGGG & 314 & low density & $17(58)$ & $24(60)$ & $53(118) / 44.9$ & 0.2501 \\
\hline K65 & PCCA/MTAC & 510 & low density & $24(58)$ & $33(60)$ & $51(118) / 43.2$ & 0.1465 \\
\hline K66 & PCCA/MTAG & 263 & low density & $19(58)$ & $36(60)$ & $43(118) / 35.6$ & $<0.05$ \\
\hline K68 & PCCA/MTCC & 188 & low density & $15(58)$ & $29(60)$ & $46(118) / 38.9$ & $<0.05$ \\
\hline K68 & PCCA/MTCC & 325 & low density & $7(58)$ & $30(60)$ & $37(118) / 31.3$ & $<0.05$ \\
\hline K70 & PCCA/MTTG & 314 & low density & $24(58)$ & $42(60)$ & $42(118) / 35.6$ & $<0.05$ \\
\hline K71 & PCCA/MTGC & 295 & low density & $16(58)$ & $38(60)$ & $38(118) / 32.2$ & $<0.05$ \\
\hline K57 & EAAC/MCGC & 500 & low density & $28(58)$ & $41(60)$ & $47(118) / 39.8$ & $<0.05$ \\
\hline K90 & EAAC/MGCC & 279 & low density & $23(58)$ & $39(60)$ & $44(118) / 37.2$ & $<0.05$ \\
\hline
\end{tabular}


Table 2. - Sequences of primers used for marker amplification A. primer sequences for the amplification of size reduced markers. B. primer sequences for the amplification of full length markers $\mathrm{RSS}=$ restriction site specific; including the recognition site for the specific restriction enzyme $(\mathrm{TTAA}=M s e \mathrm{I} ; \mathrm{CTGCAG}=P s t \mathrm{I}$, marked as bold). Size in $\mathrm{bp}, \mathrm{Tm}=$ annealing temperature.

\begin{tabular}{|c|c|c|c|c|}
\hline & primer & primer sequence $\left(5^{\prime}-3^{\prime}\right)$ & size & $\mathrm{Tm}$ \\
\hline \multirow[t]{8}{*}{$\mathbf{A}$} & K9F & CGA GGC CGT GCT AGT TAT & 101 & 58 \\
\hline & K9R & TTT GAT TTA GGA CGG CTA GT & & \\
\hline & $\mathrm{K} 37 \mathrm{~F}$ & CAG CGT GTT TTT CGT GTT CT & 183 & 58 \\
\hline & K37R & CTC TTT TCA CAG CCC AGA GG & & \\
\hline & K67F & CCA TGA CCT TGA GAA TGG AAG & 98 & 60 \\
\hline & K67R & AAG GAC ATC ATT GAC ATC CAA GG & & \\
\hline & K68F & GGG TAG CAA ATG CTC CTC CA & 198 & 60 \\
\hline & K68R & GCA GTC CTG GAA TTG GAC AG & & \\
\hline \multirow[t]{8}{*}{ B } & K9-RSS F & TTA ACA GCA GTA AGC CTT TCC GCG & 171 & 60.5 \\
\hline & K9-RSS R & CTG CAG CCA ATA TTT GAT TTA GGA C & & \\
\hline & K37-RSS F & TTA ACG CAC TGT AGT TAC CAT TTC C & 263 & 62 \\
\hline & K37-RSS R & CTG CAG CCA CAT TGC AGC GTG & & \\
\hline & K67-RSS F & CTG CAG CCA CAA TAT GTC AG & 166 & 58 \\
\hline & K67-RSS R & CTG CAG CCA TTA TCA TCA AC & & \\
\hline & K68-RSS F & CTG CAG $C C A$ GAT ACT TGC AAC TC & 325 & 62 \\
\hline & K68-RSS R & CTG CAG $C T G$ GGT AGC AAA TGC TC & & \\
\hline
\end{tabular}

Initially, sets of nested primers used for amplification (Table $2 A)$ produced monomorphic bands for all markers in nearly all individuals (94\%) regardless of marker linkage to low or high wood density. Subsequent, sets of restriction site specific (RSS) primers, including $P s t \mathrm{I}$ or $M s e \mathrm{I}$ restriction recognition sites were used (Table $2 B$ ), resulting again in an amplification of monomorphic fragments for all individuals.

A restriction approach of PCR-products obtained by using the RSS-primers (Table $2 B$ ) was performed for distinction of the marker-alleles in linkage to low or high wood density. Eighteen different restriction enzymes, adjusted to defined restriction recognition sites within PCR products, were selected based on sequence information and tested. By following this strategy, a distinction of the marker K9-171 and K37-263 was feasible. For marker K9-171, the restriction enzyme HaeIII revealed as optimal (Figure 1), whereas the marker K37-263 was distinguished by using of TaqI and BamHI enzymes (not shown).

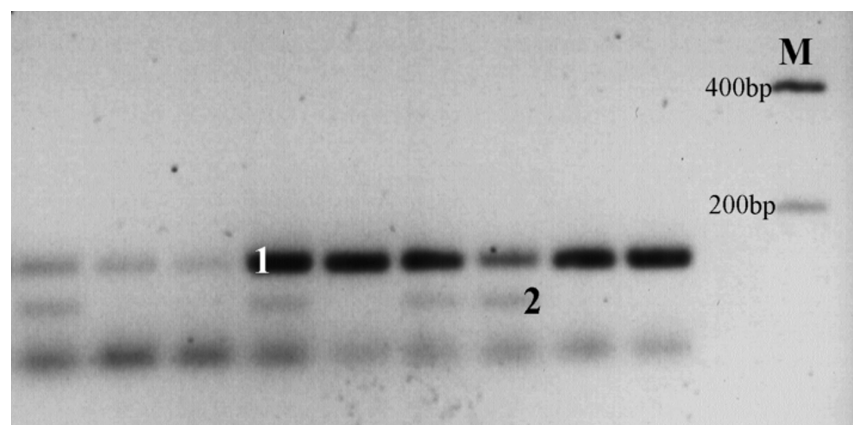

Figure 1. - Restriction pattern of marker K9-171 (1) for HaeIII restriction of full length fragments after PCR-amplification by restriction site specific (RSS)-primers. Expected marker (2, 120bp) correlated to high wood density (see also Table 3 ). $\mathrm{M}$ = Molecular weight marker.

In total 222 progenies (from 29 full-sib families) and 52 unrelated clones (Hermanstorp and Knutstorp) were analysed in respect to marker-alleles for high density marker K9-171 and K37-263. Based on mean wood density data, an ANOVA and a t-test according to LANDER and BoTSTEIN (1989) were performed to associate wood density with marker and to estimate the mean value for the marker alleles. According to the results in Table 3, both markers are applicable for selection on high wood density of Norway spruce. Based on scoring data for presence or absence of these markers, no linkage between markers was
Table 3. - Results of the statistical analyses based on data for mean wood density for the marker-alleles K37-263 and K9-171. M0 = mean density of class for marker absence; M1= mean density of class for marker presence. Mean Diff = mean difference between the classes for marker presence or absence. LSD is the least significant difference (95\% confidence limits) between the classes. $\mathrm{r}^{2}=$ percentage of phenotypic variation explained by the marker.

\begin{tabular}{lcccccc}
\hline & M0 & M1 & Mean Diff. & LSD & p-value & $r^{2}$ \\
\hline K9-171 & 396.01 & 456.90 & 60.89 & 12.13 & $<0.05$ & 18.46 \\
K37-263 & 388.59 & 441.56 & 52.97 & 9.67 & $<0.05$ & 23.71 \\
\hline
\end{tabular}

identified. The phenotypical variance which can be explained by marker K9-171 are $18.46 \%$ and $23.71 \%$ for K37-263 (Table $3)$.

\section{Discussion}

Different reports have been published for crop species about molecular markers for selected traits, which were identified by bulked segregant analysis (BSA) in combination with AFLP (NEGI et al., 2000; Dong et al., 2000; HAYES et al., 2000). For tree species, the BSA was used for the identification of RAPDs linked to Melampsora resistance in poplar (VILLAR et al., 1996), white pine blister rust fungus resistance of sugar pine (HARKINS et al., 1998), or the analysis of quantitative traits (GrattAPAGLiA et al., 1996).

Here, the development of molecular markers for high wood density of Norway spruce (Picea abies), based on BSA-AFLP combination and their conversion to SCAR marker is described for the first time. The availability of these markers, however, may also be usable for selection of other wood properties.

Negative correlations were described for wood density and growth rate or higher susceptibility to cambial damage from frost spring, respectively (VARGAS-HERNANDEZ, 1994), whereas a positive correlations between density and fibre length was reported by ZHANG (1997) and Dutilleul et al. (1998). We did not verify these markers for their correlation to fibre length, however, theoretically they are usable as an indirect predictor for fibre length, which is an important trait for pulp industry.

Nearly all AFLP-markers which were linked to wood density, originated from primer enzyme combinations PstI/MseI (Tab. 1). PstI is well known to recognize undermethylated genomic regions and therefore putatively expressed genes (KNOX and ELLIS, 2001). Even though the markers used are short in length (166-325bp), the results were supported by marker analyses on open reading frames and database comparisons, whereas similarities to ESTs (expressed sequence tags) and a phosphatase of Arabidopsis thaliana were identified. The amplification of monomorphic PCR products for AFLP converted markers, also described by De Jong et al. (1997) and MeKsem et al. (2001), indicate the existence of conserved homoplasic loci dispersed within the genome. The knowledge about the complexity of the coniferous genomes is few, comparative mapping studies point out the existence of orthologs (same locus in two species), paralogs (genes duplicated in the same species) (Devey et al., 1996) and the existence of complex gene families (KINLAW and NEALE, 1997).

To allocate the character of the markers (ortholog/paralog), different coniferous species were analysed on presence or absence of the presented markers. All four wood density markers identified for Picea abies, were also found as size identical fragments in different Pinus species (Pinus pinaster, Pinus sylvestris, Pinus radiata, not shown). Therefore, these markers might be speculated as orthologs among different conifers. An 
initial restriction of PCR-products revealed sequence differences for two of four markers between $P$. abies and $P$. pinaster Detailed information about sequence identities will be obtained by direct sequence comparisons.

The reason for amplification of monomorphic fragments by usage of nested- or restriction site specific (RSS) primer may be the nature of AFLP markers. In general, internal sets of primers are mainly used for amplifications of converted markers (Shan et al., 1999; MEKsEm et al., 2001), but AFLP fragments resulted definitively from nucleotide difference specific to AFLP primers. Despite the usage of RSS primers, an amplification of monomorphic fragments was impossible. As crucial reason, we assume a high mismatch rate for the $M s e I$ sequence (TTAA) within the restriction site-specific primer.

The conversion and examination of the residual eleven AFLP-marker as well the differentiation of the remaining two markers which are in linkage to high wood density by SSCPanalyses (PlOMion et al., 1999) will be a major task for the near future in purposes to increase the amount of markers functional for MAS (marker assisted selection) on wood density. Next a clarification of sequence identities between fragments, which is of interest not only for synteny studies, it is mainly intended to identify more markers usable to explain most of the phenotypical variance for wood density.

The orthologous character of the markers enforces the intention, to reveal potential correlations to wood density in different coniferous species. Therefore, we are in preparation to map them in Pinus pinaster, Pinus sylvestris and Pinus radiata.

It is not predictable, whether the presence of the marker within a genomic background will be a sufficient indicator, that genes which are in linkage are definitively switching during life span, resulting in an increment of wood density. Before usage of the marker for MAS, a vast validation on marker presence in different genetic backgrounds and correlation analyses to wood density are undoubtedly required.

The question, whether the markers presented here, are parts of genes which are correlated to wood density expression is not answerable at the moment based on BLAST X and BLAST N information. Therefore, a PCR-walk (SIEBERT et al., 1995; DEviC et al., 1997), tail-PCR (LIU et al., 1995) or hybridisation of the markers against an existing cDNA library for Norway spruce may help to light up the character and functionality of these markers within the coniferous genome.

\section{Acknowledgements}

This project was funded by the European Commission (FAIR-CT983953) as a part of the share cost project "GENIALITY" Genetic improvement of wood quality - increasing selection efficiency by different end uses.

We want to thank Bo KARLSON, LARS WILHELMSON and BJÖRN HANNRUP from SkogForsk (Sweden) for providing plant material and many thanks to PHILLIPE RozENBERG (INRA-Orleans) for wood density estimation by X-ray microdensity.

\section{References}

Arcade, A., Anselin, F., Faivre Rampant, P., Lesage, M. C., PÂques, L. E. and PRAT, D.: Application of AFLP, RAPD and ISSR markers to genetic mapping of European and Japanese larch. Theor. Appl. Genet. 100: 299-307 (2000). - BAMBER, R. K. and BuRLEY, J.: The properties of radiate pine. Commonwealth Agricultural Bureau, Slough. 84 pp. (1983). - Bradshaw, H. D and Stettler, R. F.: Molecular genetics of growth and development in Populus. IV. Mapping QTLs with large effects on growth, form and phenology traits in a forest tree. Genetics 139: 963-937 (1995). — Byrne, M., Murell, J. C., Owen, J. V., KreideMANN, P., Williams, E. R. and Moran, G. F.: Identification and mode of action of quantitative trait loci affecting seedling height and leaf area in Eucalyptus nitens. Theor. Appl. Genet. 94: 674-681 (1997). — ClaPHAM, D., Demel, P., Elfstrand, M., Koop, H. U., Sabala, I. and von Arnold, S.: Gene transfer of Picea abies and the Production of Transgenic
Plantlets. Scand. J. For. Res. 15: 151-160 (2000). - DE Jong, W., Forsyth, A., Leister, D., Gebhardt, C. and Baulcombe, D. C.: A potato hypersensitive resistance gene against potato virus $\mathrm{X}$ maps to a resistance gene cluster on chromosome 5. Theor. Appl. Genet. 95: 246-252 (1997). - Devey, M. E., Sewell, M. M. and Neale, D. B.: A comparison of loblolly and radiata pine genomes using RFLP markers. Tree Improvement for Sustainable Tropical Forestry (DIETERS, M. J. et al. eds), pp. 478-480 (1996). - Devic, M., Albert, S., Delseny, M. and Roscoe, J.: Efficient PCR walking on plant genomic DNA. Plant Physiol. Biochem. 35: 331-339 (1997). — Dong, N. V., SubudHI, P. K., LounG, P. N., Quang, V. D., Quy, T. D., Zheng, H. G., WANG, B. and NguYen, H. T. Molecular mapping of a rice gene conditioning thermosensitive genic male sterility using AFLP, RFLP and SSR techniques. Theor. Appl. Genet. 100: 727-734 (2000). — Dutilleul, P., Herman, M. and AvellaSHAw, T.: Growth rate effects on correlation among ring width, wood density, and mean tracheid length in Norway spruce (Picea abies). Can J. For. Res. 28: 56-68 (1998). - Dumolin, S., Demesure, B. and Petit, R. J.: Inheritance of chloroplast and mitochondrial genomes in pedunculate oak investigated with an efficient PCR method. Theor. Appl. Genet. 91: 1253-1256 (1995). - Grattapaglia, D., Bertoluci, F. L. G. PENCHEL, R. and SEDEROFF, R. R.: Genetic mapping of quantitative trait loci controlling growth and wood quality traits in Eucalyptus grandis using a maternal half-sib family and RAPD markers. Genetics 144 1205-1214 (1996). - Groover, A., Devey, M., Fiddler, T., Lee, J., Megraw, R., Mitchel-Olds, T., Sherman, B., Vujcic, S., William, C. and NEALE, D.: Identification of quantitative trait loci influencing wood specific gravity in an outbred pedigree of Loblolly Pine. Genetics 138 1293-1300 (1994). - Harkins, D. M., Johnson, G. N., SkagGs, P. A., Mix, A. D., Dupper, G. E., Devey, M. E., Kinloch, B. B. and Neale, D. B.: Saturation mapping of a major gene for resistance to white pine blister rust in sugar pine. Theor. Appl. Genet. 97: 1355-1360 (1998). Hayes, A. J. and SAghai Maroof, M. A.: Targeted resistance gene mapping in soybean using modified AFLPs. Theor Appl Genet 100: 1279-1283 (2000). - KenNeDY, R. W.: Coniferous wood quality in the future: concerns and strategies. Wood Science and Technology 29 321-338 (1995). - KinlaW, C. S. and Neale, D. B.: Complex gene families in pine genomes. Trends in Plant Science 9: 356-359 (1997). Knox, M. R. and Ellis, T. H. N.: Stability and inheritance of methylation states at PstI sites in Pisum. Mol. Genet. Genomics. 265: 497-507 (2001). - Kumar, S., Spelman, R. J., Garrick, D. J., Richardson, T. E., Lausberg, M. and Wilcox, P. L.: Multiple-marker mapping of wood density loci in an outbreed pedigree of radiata pine. Theor. Appl. Genet. 100: 926-933 (2000). - LANDER, E. S. and Botstein, D.: Mapping mendelian factors underlying quantitative traits using RFLP linkage maps. Genetics 121: 185-199 (1989). — Lerceteau, E., Plomion, C. and ANDERSON, B.: AFLP mapping and detection of quantitative trait loci (QTLs) for economically important traits in Pinus sylvestris: a preliminary study. Molecular Breeding 6: 451-458 (2000). — LIU, Y. G., MITSUKAWA, N., Oosumi, T. and WhiTTIER, R. F.: Efficient isolation and mapping of Arabidopsis thaliana T-DNA junctions by thermal asymmetric interlaced PCR. The Plant Journal 8: 457-463 (1995). — LÓPEZ, M., Humara, J. M., RoDriguez, R. and OrdÁs, R.: Transient uidA gene expression in electroporated cotyledonary prototplast of Pinus nigra ssp. salzmannii and in bombarded cotyledons. Can. J. For. Res. 30 448-455 (2000). - McKay, J. J., Liu, W., Whetten, R., Sederoff, R. R and O'MALLEY, D.: Genetic analysis of cinnamyl alcohol dehydrogenase in loblolly pine: single gene inheritance, molecular characterization and evolution. Mol. Gen. Genet. 247: 537-545 (1995). - MEKsEM, K., RUBEN, E., Hyten, D., Triwitayakorn, K. and Lightfoot, D. A.: Conversion of AFLP bands into high-throughput DNA markers. Mol. Genet. Genomics. 265: 207-214 (2001). - Michelmore, R. W., PARAN, I. and Kesseli, R.V.: Identification of markers linked to disease resistance genes by bulked segregant analysis: a rapid method to detect markers in specific genomic regions by using segregating populations. Proc. Natl. Acad. Sci. USA 88: 9828-9832 (1991). — Negi, M. S., Devic, M., DelseNY, M. and LAKSHMIKUMARAN, M.: Identification of AFLP fragments linked to seed coat colour in Brassica junicea and conversion to a SCAR marker for rapid selection. Theor. Appl. Genet. 101: 146-152 (2000). Oberhagemann, P., Chatot-Balandras, C., Schäfer-Pregl, R., Wegener, D., Palomino, C., Salamini, F., Bonnel, E. and Gebhardt, C.: A genetic analysis of quantitative resistance to blight in potato: towards marker-assisted selection. Molecular Breeding 5: 399-415 (1999). Plomion, C., Bahrman, N., Durel, C. E. and O'Malley, D. M.: Genomic mapping in Pinus pinaster (maritime pine) using RAPD and protein markers. Heredity 74: 661-668 (1995). - Plomion, C., Durel, C. E. and O'MALLEY, D. M.: Genetic dissection of height in maritime pine seedlings raised under accelerated growth conditions. Theor. Appl. Genet. 93: 849-858 (1996). - Plomion, C., Hurme, P., Frigerio, J. M., Ridolfi, M., Pot, D., Pionneau, C., Avila, C., Gallardo, F., David, H., Neutelings, G., Campbell, M., Canovas, F. M., Savolainen, O., BodÉnÈs, C. and Kremer, A.: Developing SSCP markers in two Pinus species. Molecular Breeding 5: 21-31 (1999). - PolgE, H.: Etablissement des Courbes de Variation de la Densité du Bois par Exploration 
Densitométrique de Radiographies D'Echantillons Prélevé à la Tarière sur des Abres Vivants. Aplication dans les domaines technologiques et physiologiques, thèse de doctorat, Université de Nancy, France, 206p. (1966). - Remmington, D. L., Whetten, R. W., Liu, B. H. and O’Malley, D. M.: Construction of an AFLP genetic map with nearly complete genome coverage in Pinus taeda. Theor. Appl. Genet. 98: 1279-1292 (1999)... - Ritter, E., Aragones, A., Markussen, T., Acheré, V. Espinel, S., Fladung, M., Wrobel, S., Faivre-Rampant, P., Jeandroz, S. and FAVRe, J. M.: Towards construction of an ultra high density linkage map for Pinus pinaster. Ann. For. Sci. 59: 637-643 (2002). Rozenberg, P. and Franc, A.: Modelling wood modules of elasticity using density profiles: methods and genetic effects. Second IUFRO Workshop: Connection between silviculture and wood quality through modelling approaches and simulation software. Kruger National Park, South Africa, August 26-31 (1996). - Rozenberg, P. and CAHAlan, C. Spruce and wood quality: genetic aspects. Silvae Genetica 46: 270-79 (1997). - Rozenberg, P., Franc, A. and Cahalan, C.: Incorporating Wood density in Breeding Programs for Softwoods in Europe: a Strategy and Asscociated methods. Silvae Genetica 50: 1-7 (2001). — SEDEROFF, R.: Building better trees with antisense. Nature Biotechnology $\mathbf{1 7}$ 750-751 (1999). - Sewell, M. M., Bassoni, D. L., Megrav, R. A. WheEler, N. C. and NeAle, D. B.: Identification of QTLs influencing wood property traits in loblolly pine (Pinus taeda L.). I. Physical wood properties. Theor. Appl. Genet. 101: 1273-1281 (2000). — SHAN, X. BLAKE, T. K. and TALBERT, L. E.: Conversion of AFLP markers to sequence-specific PCR markers in barley and wheat. Theor. Appl. Genet. 98: 1072-1078 (1999). - ShePard, M., Chaparro, J. X. and TEAS DALE, R.: Genetic mapping of monoterpene composition in an interspecific eucalypt hybrid. Theor. Appl. Genet. 99: 1207-1215 (1999). -
Siebert, P. D., Chenchick, A., KellogG, D. E., Lukyanov, K. A. and LUKYANOV, S. A.: An improved PCR method for walking in uncloned genomic DNA. Nucleic Acids Res. 23: 1087-1088 (1995). — THAMARUs, K., Groom, K., Murell, J. and Moran, G.: A genetic map and QTL analysis of wood and pulp traits in Eucalyptus globolus. Hybrid Breeding and Genetics of Forest Trees, Proceedings of QFRI/CRC-SNF Symposium, 9-14 April 2000, Noosa, Queensland, Australia, pp. 510-513. (Compiled by Dungey, H. S., Dieters, M. J. and Nikles, D. G.) Department od Primary Industries, Brisbane (2000). - VARGAS-HERNANDEZ J. and ADAMS, W. T.: Genetic relationships between wood density components and cambial growth rhythm in young coastal Douglas-fir. Can. J. For. Res. 24: 1871-1876 (1994). - Villar, M., LefÈVRe, F., BradshaW, H. D. and TeIssier DU Cros, E.: Molecular genetics of rust resistance in poplars (Melampsora larici-populina Kleb/Populus sp.) by bulked segregant analysis in a 2 × 2 factorial mating design. Genetics 143: 531-536 (1996). - Vos, P., Hogers, R., Bleeker, M., Reijans, M., van der Lee, T., Hornes, M., FriJters, A., Pot, J., Peleman, J., Kuiper, M. and ZABEAU, M.: AFLP: a new concept for DNA fingerprinting. Nucleic Acids Res. 23: 4407-4414 (1995). — Williams, J. G. K., KUBELIK, A. R., LivaK, K. J., RAFALSKI, J. A. and TINGEY, S. V.: DNA polymorphisms amplified by abitrary primers are useful as genetic markers. Nucl. Acids Res. 18 6531-6535 (1991). - Wu, R. L., Remington, D. L., MacKay, J. J., McKEAND, S. E., O'MALley, D. M.: Average effect of a mutation in lignin biosynthesis in loblolly pine. Theor. Appl. Genet. 99: 705-710 (1999). ZHANG, X. H. and CHIANG, V. L.: Molecular cloning of 4-coumarate: coenzyme A ligase in loblolly pine and the roles of this enzyme in the biosynthesis of lignin in compression wood. Plant Physiol. 113: 65-74 (1997). - Zobel, B. J. and van BuIJTENEN, J. P.: Wood variation: its causes and control. Springer-Verlag, Berlin, 363 pp. (1989).

\title{
Clonal Propagation of Dalbergia sissoo Roxb. by Softwood Nodal Cuttings: Effects of Genotypes, Application of IBA and Position of Cuttings on Shoots
}

\author{
By A. Husen*
}

Plant Physiology, Botany Division, Forest Research Institute, P.O. New Forest, Dehra Dun-248006, India

(Email: adroot92@yahoo.co.in)

(Received $9^{\text {th }}$ January 2003)

\begin{abstract}
Summary
Softwood nodal shoot cuttings were collected from the hedge garden at New Forest campus of Forest Research Institute, Dehra Dun. The cuttings were rooted in mist chamber to investigate the effect of IBA application and position of cuttings on shoots on rooting ability in different clones of Dalbergia sissoo Roxb. As compared to the $0 \%$ (control) and $0.1 \% ; 0.2 \%$ IBA showed maximum adventitious root formation. Overall percent rooting, percent sprouting, mean number of shoots and their length, mean number of roots and their length increased with increasing concentration of IBA. Among different positions of cuttings within the shoots, the best rooting response was recorded in the middle part followed lower and upper part. The findings exhibited significant interclonal variation regarding adventitious rooting and maximum response was observed in C42 (Gonda, Uttar Pradesh) clone. Interactive effect of clone C42 and middle position significantly increased percent sprouting while; interactive effects of middle position and $0.2 \%$ IBA treatment significantly increased percent rooting. It is concluded that the selection of genotypes with good rooting ability with respect to shoot position in hedged plants and concentration of IBA can be made to produce high quality planting stock material to start clonal forestry programme of $D$. sissoo.
\end{abstract}

* Present address for communication: Department of Botany, Faculty of Applied Science, University of Gondar, PO Box 196, Gondar, Ethiopia.
Key words: Dalbergia sissoo, IBA, position on shoots, clone, nodal cuttings, rooting.

\section{Introduction}

Dalbergia sissoo Roxb. commonly known as shisham is an important multipurpose tree species of Northern India. Traditionally, plantations of this species are raised through seedling resulting in large variation in growth, form, irregular seed setting and disease prone trees. In order to reduce plant variability and at the same time ensure increased productivity, the development of vegetative/clonal propagation techniques is required. For the production of high quality timber and faster tree growth, it is essential to start by selecting superior clones/trees from which the stem shoot cuttings are to be taken. Vegetative propagation of shisham and other tree species through stem cuttings is markedly affected by several factors (NANDA, 1970; HARTMANN et al., 1997). Several studies have demonstrated variation in rooting ability within genotypes on the same locations due to natural genetic variation (HAINes et al., 1992; Husen and PAL, 2003a). Positions from which cuttings are taken also influence the overall quality, its ability to root and subsequent growth habit (HARTMANN et al., 1997; ZAKARIA and ONG, 1982; TCHOUNDJEU and LEAKEY, 1996; HUSEN and PAL, 2003b). Adventitious root formation in juvenile 